\title{
Androgen receptor expression in the urinary bladder urothelial carcinoma and its relation to known prognostic factors
}

\author{
Eman T. El-taher ${ }^{1}$, Maha Lotfy Zamzam ${ }^{1}$, Ahmed Mustafa Elzawawy ${ }^{1}$, Wael Abdo Hassan ${ }^{2,3}$, Marwa A. Suliman*1 \\ ${ }^{1}$ Clinical Oncology \& Nuclear Medicine Department, Faculty of Medicine, Suez Canal University, Egypt \\ ${ }^{2}$ Pathology Department, Faculty of Medicine, Suez Canal University, Egypt \\ ${ }^{3}$ Department of Basic Sciences, Sulaiman Al Rajhi University, Al Bukayriyah, KSA
}

Received: August 10, 2020

DOI: $10.5430 /$ jst.v10n2p22
Accepted: September 23, $2020 \quad$ Online Published: October 22, 2020

URL: https://doi.org/10.5430/jst.v10n2p22

\begin{abstract}
Objective: The current study was carried out to assess the prognostic value of androgen receptor expression in urothelial carcinoma of the bladder and correlate it to the disease outcome.

Methods: Histologically confirmed cases of bladder urothelial carcinoma were studied. Clinical, pathological, and radiological data were collected. Paraffin embedded tissue sections were submitted for hematoxylin and eosin staining, as well as immunohistochemical staining for androgen receptor in tumor cells.

Results: Nuclear androgen receptor expression was positive in $75 \%$ of the studied histopathological specimens. Additionally, a significant positive association between androgen receptor expression and tumor grade, muscle invasion \& tumor size were noticed.

Conclusions: There is a significant association between large tumor size, high grade, deep invasion, and expression of Androgen receptor in urothelial bladder carcinoma. Antiandrogen could be an effective chemo preventive or therapeutic approach in treatment of urothelial bladder carcinoma.
\end{abstract}

Key Words: Androgen receptor, Urothelial carcinoma, Pathology, Prognostic factor

\section{INTRODUCTION}

Globally, Bladder cancer (BC), is ranked the 10th most frequent type of cancer. ${ }^{[1]}$ In Egypt, it represents the third most frequent cancer and the second one among men. ${ }^{[2]}$

Among genitourinary tumors, urothelial bladder carcinoma (UC) is the second most common malignancy, and also the second one causing death. ${ }^{[3,4]}$ Clinically, It has two main subtypes; non muscle invasive and muscle invasive UC. ${ }^{[5]}$

Treatment efficacy of non-muscle invasive UC is usually lim- ited, and about half of the patients have tumor recurrence or progression, despite complete transurethral resection then adjuvant and maintenance intravesical chemotherapy or immunotherapy according to risk stratification. Also, patients with muscle invasive UC frequently develop progressive disease after radical cystectomy and systemic chemotherapy. ${ }^{[6]}$

Over the past three decades, treatment options have remained unchanged, thereby highlighting the need for further research on the molecules and pathways that are responsible for dis-

\footnotetext{
*Correspondence: Marwa A. Suliman; Email: Marwa_awad2008@yahoo.com; Address: Clinical Oncology \& Nuclear Medicine Department, Faculty of Medicine, Suez Canal University, Egypt.
} 
ease development and the possibility of providing new targeted therapy. ${ }^{[7]}$

Epidemiologically, UC is more common in men than women. ${ }^{[8]}$ Smoking and industrial chemicals were blamed for the male predominance but it seems not enough alone to explain such obvious difference. ${ }^{[9]}$ It has been shown that androgen promote urothelial carcinogenesis and progression via the androgen receptor (AR) pathway both in vitro and vivo ${ }^{[10]}$ Furthermore, clinical studies have also noticed that androgen deprivation treatment used for prostate cancer patients can prevent development and recurrence of UC. ${ }^{[11]}$

The urinary bladder and prostate originates from the urogenital sinus and this may suggest the possible role of androgens and AR in the urinary bladder carcinogenesis. ${ }^{[12]}$

Generally speaking, AR is a nuclear steroid hormone receptor, composed of several domains, N-terminal domain, DNA binding domain, a hinge region and a ligand binding domain. Androgen receptors are cytoplasmic receptors, that when bind to androgen, the androgen-AR complex translocate into the nucleus, followed by transcription of several genes. ${ }^{[13-15]}$

In addition to its possible role in urothelial carcinogenesis, AR signaling plays a significant role in prostate cancer occurrence and progression. ${ }^{[16]}$

Our study was aimed to investigate the expression of AR in urinary bladder urothelial carcinoma and correlate between AR expression and the clinicopathological features of the tumor and the disease outcome after 5 years follow up.

\section{Patients and methods}

This descriptive study included 44 histopathologically confirmed cases of UC of the urinary bladder treated at Suez Canal University (SCU) Hospital, at Clinical Oncology and Nuclear Medicine Department, from January 2010 to December 2014. The initial pathological diagnosis was done at the Pathology lab of the SCU hospital, where their paraffin blocks are available for the immunohistochemical assessment.

\subsection{Patient's clinical data}

The following clinicopathological data were collected from the file-recording system of SCU Hospital, Clinical Oncology and Nuclear Medicine Department archive: age at diagnosis, gender, address, occupation, smoking and history of bilharziasis. In addition, follow up data for each patient were retrieved: treatment received either chemotherapy or radiotherapy or supportive care, periodic assessment, treatment response and time to disease recurrence or progression.

\subsection{Pathological data}

\subsubsection{Histopathological evaluation}

All available patients' pathological slides stained with hematoxylin and eosin (H\&E) has been reviewed, for assessment of tumor stage and grade; according to 8th edition of the AJCC TNM classification ${ }^{[17]}$ and to 2004 World Health Organization (WHO) / International Society of Urological Pathology (ISUP) classification of urothelial neoplasms. ${ }^{[18]}$ Paraffin embedded tissue sections have been submitted for immunohistochemical (IHC) staining.

\subsubsection{Immunohistochemical staining and evaluation}

Formalin fixed paraffin embedded specimens were cut and submitted for immunohistochemical staining. Sections were heated with autoclave for antigen retrieval. Slides were then incubated with primary anti-AR antibody (Abcam; EPR1535 (2); Cambridge, UK), at $4^{\circ} \mathrm{C}$ overnight. This was followed by incubation with a propriate secondary antibody for 1 hour, after which slides were counterstained with hematoxylin stain and observed by an independent pathologist.

Table 1. The Clinicopathological parameters of the studied patients

\begin{tabular}{|c|c|c|c|}
\hline \multicolumn{2}{|l|}{ Variables } & $\begin{array}{l}\text { Number } \\
(N=44)\end{array}$ & $\%$ \\
\hline & $\begin{array}{l}\text { Mean } \pm \text { SD } \\
\text { (Range) }\end{array}$ & \multicolumn{2}{|c|}{$\begin{array}{c}64.61 \pm 9.55 \\
41\end{array}$} \\
\hline \multirow[t]{2}{*}{ Age (years) } & $>55$ & 37 & 84.09 \\
\hline & $\leq 55$ & 7 & 15.91 \\
\hline \multirow[t]{2}{*}{ Gender } & Male & 38 & 86.36 \\
\hline & Female & 6 & 13.64 \\
\hline \multirow[t]{2}{*}{ Bilharziasis } & Negative & 33 & 75 \\
\hline & Positive & 11 & 25 \\
\hline \multirow[t]{2}{*}{ Smoking } & No & 16 & 36.36 \\
\hline & Yes & 28 & 63.64 \\
\hline Muscle & NMI & 8 & 18.18 \\
\hline Invasion & MI & 36 & 81.82 \\
\hline \multirow[t]{6}{*}{ Tumor stage } & Cis & 0 & 0 \\
\hline & $\mathrm{Ta}$ & 1 & 2.27 \\
\hline & $\mathrm{T} 1$ & 8 & 18.18 \\
\hline & $\mathrm{T} 2$ & 12 & 27.27 \\
\hline & T3 & 14 & 31.82 \\
\hline & $\mathrm{T} 4$ & 9 & 20.46 \\
\hline \multirow[t]{2}{*}{ Tumor size } & $\leq 3 \mathrm{~cm}$ & 13 & 29.55 \\
\hline & $>3 \mathrm{~cm}$ & 31 & 70.45 \\
\hline \multirow[t]{2}{*}{ Grading } & Low Grade & 9 & 20.45 \\
\hline & High Grade & 35 & 79.55 \\
\hline $\mathrm{LN}$ & Yes & 5 & 11.36 \\
\hline involvement & No & 39 & 88.64 \\
\hline Distant & Yes & 3 & 6.82 \\
\hline metastasis & No & 41 & 93.18 \\
\hline \multirow[t]{2}{*}{ Tumor number } & Single & 28 & 63.64 \\
\hline & Multiple & 16 & 36.36 \\
\hline
\end{tabular}




\subsubsection{Immunohistochemical scoring}

The nuclear expression of AR in tumor cells has been observed. Scoring has been performed using a previously approved method ${ }^{[19]}$ In brief, immunoreactive score is calculated by the sum of the percentage of immunoreactive cells and the staining intensity score: no staining is scored as 0 , $1 \%-10 \%$ of cells stained is scored as $1,11 \%-50 \%$ is scored as $2,51 \%-80 \%$ is scored as 3 and $81 \%-100 \%$ is scored as 4. According to Staining intensity it is classified as negative (score o), weak (score1), moderate (score 2), strong (score 3). Immunoreactive score of 0 or 1 were considered negative and those with an immunoreactive score $\geq 2$ were considered positive(see Figures 1 and 2).

\subsection{Statistical analysis}

Data were tabulated and analyzed using the graph pad prism version 7 . Data has been analyzed by the following statistical tests: 1) Chi-square $\left(\chi^{2}\right)$ test was used to analyze categorical data that were presented as numbers and percentages. 2) Quantitative data were expressed as a mean \pm standard deviation, median, and range. 3) Spearman's rank order correlation was used to measure the association between AR expression and clinicopathological variables. 4) Kaplan Meier curve was used to assess both recurrence free survival and progression free survival among the patients according to the AR expression. Log-Rank test was used to compare survival between groups. 5) A $p$-value of 0.05 or less has been considered statistically significant.

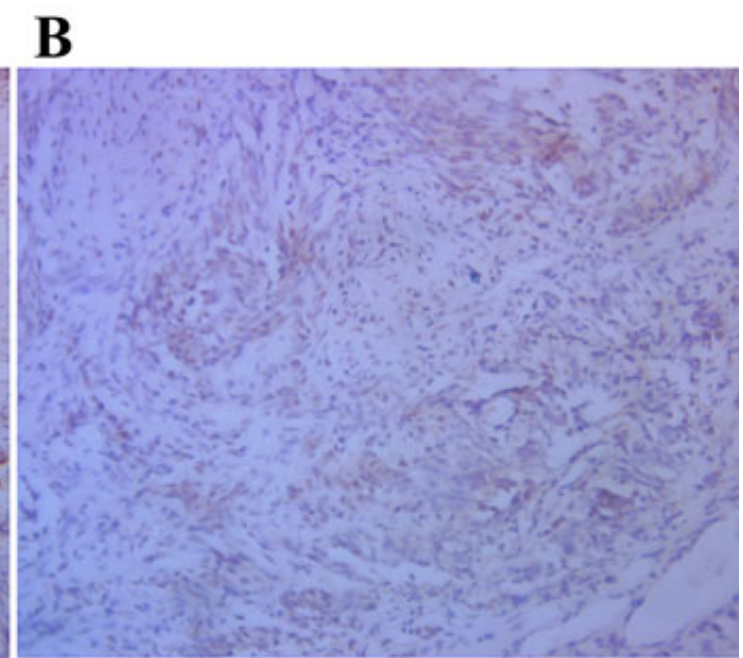

Figure 1. Immunohistochemical expression of AR in non-muscle invasive low-grade urothelial carcinoma; A) Weak AR expression $(\times 10)$; B) Weak AR expression $(\times 20)$

A

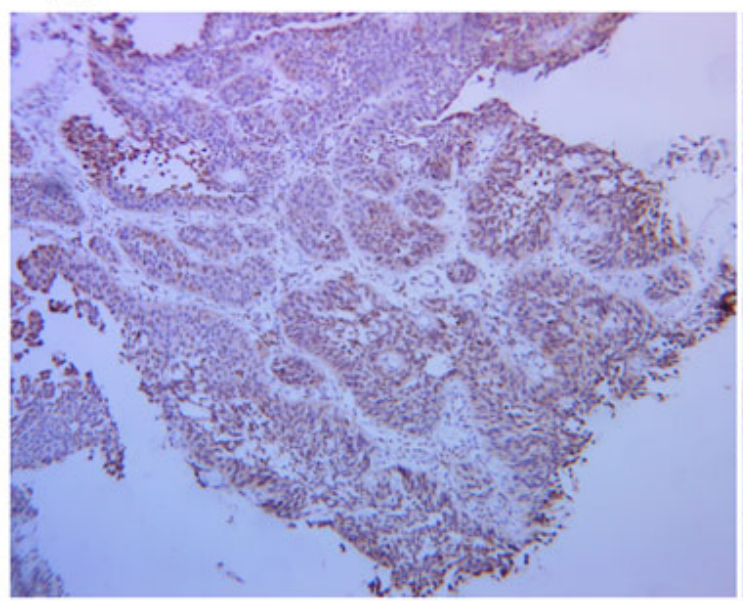

B

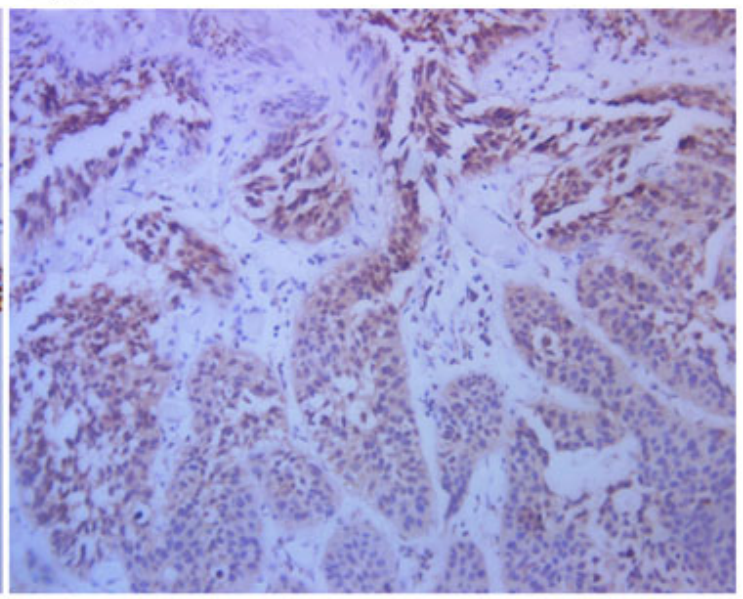

Figure 2. Immunohistochemical expression of AR in muscle invasive high-grade urothelial carcinoma; A) Moderate AR expression $(\times 10)$; B) Moderate AR expression $(\times 20)$ 
Table 2. The distribution and comparison of the Clinicopathological variables according to the AR status

\begin{tabular}{|c|c|c|c|c|}
\hline Variables & $\begin{array}{l}\text { Total } \\
(N=44)\end{array}$ & $\begin{array}{l}(\mathrm{AR}+) \\
(\mathrm{N}=33)\end{array}$ & $\begin{array}{l}(\text { AR- }) \\
(\mathrm{N}=11)\end{array}$ & $\begin{array}{l}\text { Correlation with } \mathrm{AR} \\
P \text { value }\end{array}$ \\
\hline \multirow{2}{*}{ Age (years) } & $>55(\mathrm{n}=37)$ & 29 & 8 & \multirow{2}{*}{0.275} \\
\hline & $\leq 55(\mathrm{n}=7)$ & 4 & 3 & \\
\hline \multirow{2}{*}{ Gender } & Male $(\mathrm{n}=38)$ & 29 & 9 & \multirow{2}{*}{0.251} \\
\hline & Female $(\mathrm{n}=6)$ & 4 & 2 & \\
\hline \multirow{2}{*}{ Bilharziasis } & No $(\mathrm{n}=33)$ & 26 & 7 & \multirow{2}{*}{0.578} \\
\hline & Yes $(n=11)$ & 7 & 4 & \\
\hline \multirow{2}{*}{ Smoking } & No $(n=16)$ & 15 & 1 & \multirow{2}{*}{0.958} \\
\hline & Yes $(\mathrm{n}=28)$ & 18 & 10 & \\
\hline \multirow{2}{*}{ Muscle Invasion } & NMI $(\mathrm{n}=8)$ & 1 & 7 & \multirow{2}{*}{$<0.001 * * *$} \\
\hline & MI (n = 36) & 32 & 4 & \\
\hline \multirow{6}{*}{ Tumor stage } & Cis $(\mathrm{n}=0)$ & 0 & 0 & \multirow{6}{*}{$<0.001 * * *$} \\
\hline & $\mathrm{Ta}(\mathrm{n}=1)$ & 0 & 1 & \\
\hline & $\mathrm{T} 1(\mathrm{n}=8)$ & 2 & 6 & \\
\hline & $\mathrm{T} 2(\mathrm{n}=12)$ & 9 & 3 & \\
\hline & $\mathrm{T} 3(\mathrm{n}=14)$ & 14 & 0 & \\
\hline & $\mathrm{T} 4(\mathrm{n}=9)$ & 8 & 1 & \\
\hline \multirow{2}{*}{ Tumor size } & $\leq 3 \mathrm{Cm}(\mathrm{n}=13)$ & 7 & 6 & \multirow{2}{*}{$0.034 *$} \\
\hline & $>3 \mathrm{Cm}(\mathrm{n}=31)$ & 26 & 5 & \\
\hline \multirow{2}{*}{ Grading } & L Grade $(n=9)$ & 1 & 8 & \multirow{2}{*}{$<0.001 * * *$} \\
\hline & H Grade $(n=35)$ & 32 & 3 & \\
\hline \multirow{2}{*}{ LN involvement } & Yes $(n=5)$ & 3 & 2 & \multirow{2}{*}{0.444} \\
\hline & No $(n=39)$ & 30 & 9 & \\
\hline \multirow{2}{*}{ Distant metastasis } & Yes $(n=3)$ & 3 & 0 & \multirow{2}{*}{0.806} \\
\hline & No $(n=41)$ & 30 & 11 & \\
\hline \multirow{2}{*}{ Tumor number } & Single $(\mathrm{n}=28)$ & 24 & 4 & \multirow{2}{*}{0.174} \\
\hline & Multiple $(\mathrm{n}=16)$ & 9 & 7 & \\
\hline
\end{tabular}

Note. ${ }^{*}$ statistically significant $(\mathrm{p} \leq 0.05), * * *$ highly statistically significant $(\mathrm{p} \leq 0.001)$

Table 3. Spearman's rank correlation between the studied variables

\begin{tabular}{llllllllllllll}
\hline & Sex & Age & Smoking & Grading & Staging & Number & $\begin{array}{l}\text { Muscl } \\
\text { Inv }\end{array}$ & LN Mets. DM & \multicolumn{2}{l}{ Tumor } & \multicolumn{2}{l}{ Bilharz. Specimen AR } \\
\hline Sex & 1 & 0.1641 & 0.4491 & 0.03731 & -0.09242 & 0.1425 & -0.1561 & 0.1461 & 0.1075 & 0.2677 & 0.07647 & 0.0664 & -0.09931 \\
Age & 0.1641 & 1 & -0.1348 & 0.1035 & 0.1764 & -0.2022 & 0.156 & 0.1362 & -0.0154 & 0.2256 & 0.04708 & -0.263 & 0.1681 \\
Residence & 0.5005 & -0.1109 & & -0.03541 & -0.2731 & 0.1655 & -0.2686 & 0 & 0.1406 & 0.01412 & 0.04751 & 0.1252 & -0.03294 \\
Urban/Rular & 0.1783 & -0.1002 & 0.2403 & -0.08088 & -0.229 & 0.03058 & -0.2169 & 0.004587 & 0.1009 & -0.2582 & -0.151 & -0.00892 & -0.1708 \\
Smoking & 0.4491 & -0.1348 & 1 & 0.3307 & 0.4237 & -0.3228 & 0.3307 & & -0.3086 & 0.04134 & 0.1268 & 0.09356 & 0.0129 \\
Grading & 0.03731 & 0.1035 & 0.3307 & 1 & 0.5312 & -0.3884 & 0.7835 & 0.17 & -0.1372 & 0.3927 & 0.2277 & 0.1816 & 0.7208 \\
Staging & -0.09242 & 0.1764 & 0.4237 & 0.5312 & 1 & -0.4654 & 0.6982 & -0.2185 & -0.1943 & 0.5733 & 0.2358 & 0.05752 & 0.4981 \\
Number & 0.1425 & -0.2022 & -0.3228 & -0.3884 & -0.4654 & 1 & -0.5622 & 0.01992 & 0.01276 & -0.2147 & -0.1149 & -0.1846 & -0.2384 \\
Muscl Inv & -0.1561 & 0.156 & 0.3307 & 0.7835 & 0.6982 & -0.5622 & 1 & -0.1734 & -0.1275 & 0.3927 & 0.2722 & 0.1688 & 0.5965 \\
LN Mets. & 0.1461 & 0.1362 & & 0.17 & -0.2185 & 0.01992 & -0.1734 & 1 & 0.2644 & -0.02193 & -0.0464 & -0.3211 & 0.1199 \\
DM & 0.1075 & -0.0154 & -0.3086 & -0.1372 & -0.1943 & 0.01276 & -0.1275 & 0.2644 & 1 & -0.1455 & 0.05206 & 0.09685 & -0.03803 \\
Tumor size & 0.2677 & 0.2256 & 0.04134 & 0.3927 & 0.5733 & -0.2147 & 0.3927 & -0.02193 & -0.1455 & 1 & 0.08051 & -0.1801 & 0.3497 \\
Bilharz. & 0.07647 & 0.04708 & 0.1268 & 0.2277 & 0.2358 & -0.1149 & 0.2722 & -0.0464 & 0.05206 & 0.08051 & 1 & 0.2067 & 0.08609 \\
treatment R & -0.2972 & 0.3766 & 0.2871 & 0.5784 & 0.6582 & -0.4034 & 0.7783 & -0.1235 & -0.4263 & 0.4096 & 0.1275 & -0.2073 & 0.3794 \\
Occupation & -0.2765 & 0.2655 & 0.05487 & 0.1103 & 0.1242 & 0.0305 & 0.2281 & 0.07069 & 0.01961 & 0.05577 & 0.03881 & -0.1682 & 0.03761 \\
Specimen & 0.0664 & -0.263 & 0.09356 & 0.1816 & 0.05752 & -0.1846 & 0.1688 & -0.3211 & 0.09685 & -0.1801 & 0.2067 & 1 & 0.1309 \\
AR & -0.09931 & 0.1681 & 0.0129 & 0.7208 & 0.4981 & -0.2384 & 0.5965 & 0.1199 & -0.03803 & 0.3497 & 0.08609 & 0.1309 & 1 \\
\hline
\end{tabular}




\section{Results}

\subsection{Clinicopathological data}

Patients' data were summarized in Table 1. In summary, patients mean age was $64.6 \pm 9.5$ (range $42-83$ years). The majority of the patients (84.09\%) were above 55 years. Male to female ratio was $6.3: 1$. The maximum percentage $(80.95 \%)$ was from rural areas. Regarding risk factors for $\mathrm{BC}$, the majority of the patients $(63.64 \%)$ were smokers and only $25 \%$ of the patients had bilharzial bladder disease. The majority of the patients had high grade UC $(79.55 \%)$ and muscle invasive disease $(81.82 \%)$. Fourteen patients $(31.82 \%)$ were staged T3, twelve patients $(27.27 \%)$ were staged T2, nine patients $(20.46 \%)$ were staged T4, eight patients $(18.18 \%)$ were staged $\mathrm{T} 1$ and one patient $(2.27 \%)$ was staged Ta disease.

Multifocal lesions were found in (36.36\%) of the patients. Only three patients $(6.82 \%)$ had distant metastasis from the start and the sites of metastasis were bone and liver.

\subsection{Immunohistochemical results}

Positive nuclear AR expression was found in $75 \%$ of the studied cases and the majority (61.36\%) was strongly positive for AR expression (see Figures 3 and 4). AR expression is not different between males and females $(p \leq .251)$. AR expression is significantly associated with high-grade tumors $(p \leq$ $.001)$, advanced stage disease $(p \leq .001)$, muscle invasion $(p$ $\leq .001)$ and large tumor size $(p \leq .03)$. Other clinicopathologic parameters didn't show significant association with AR expression, as detailed in Tables 2 and Table 3.

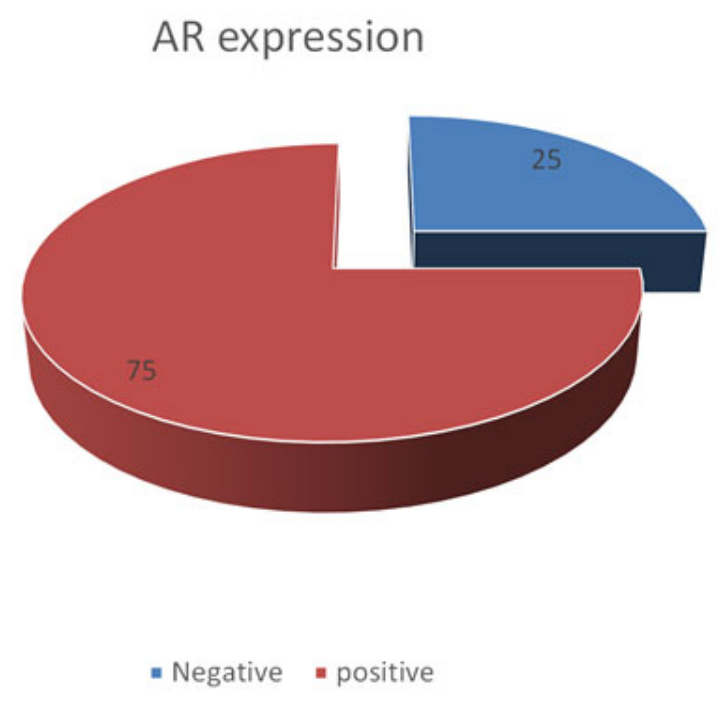

Figure 3. AR positive Vs AR negative patients

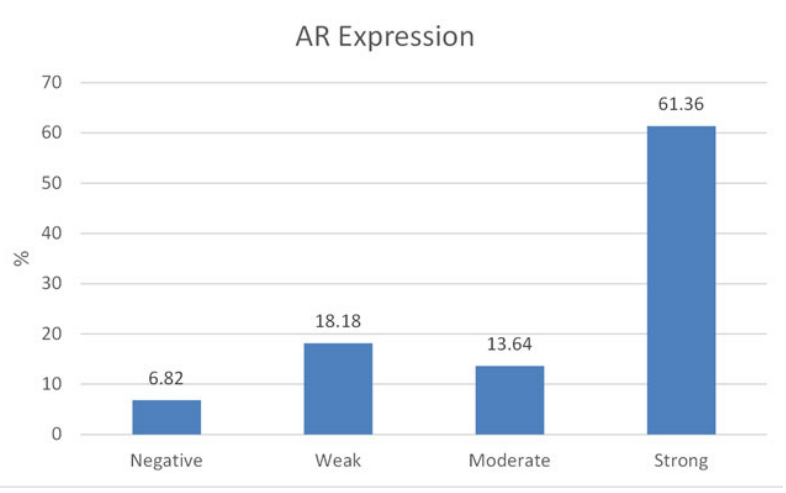

Figure 4. Distribution of AR expression among the patients

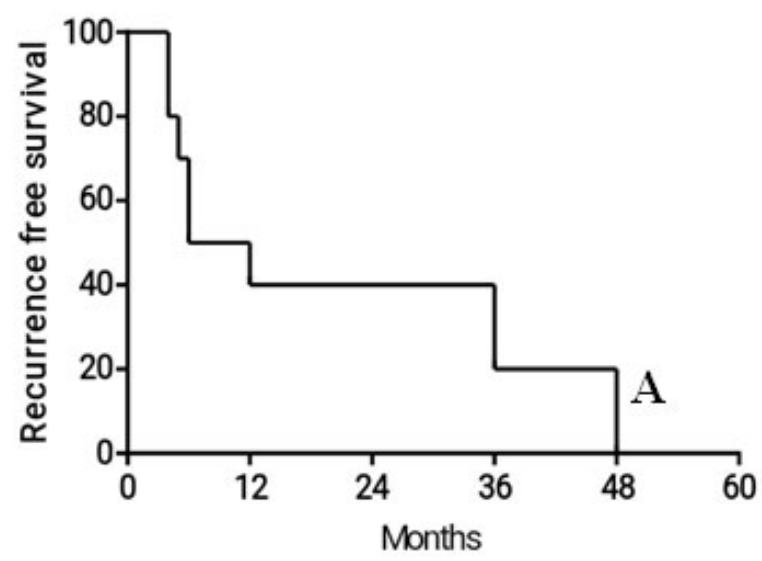

Figure 5. Kaplen Meier curve for recurrence free survival among all the studied patients

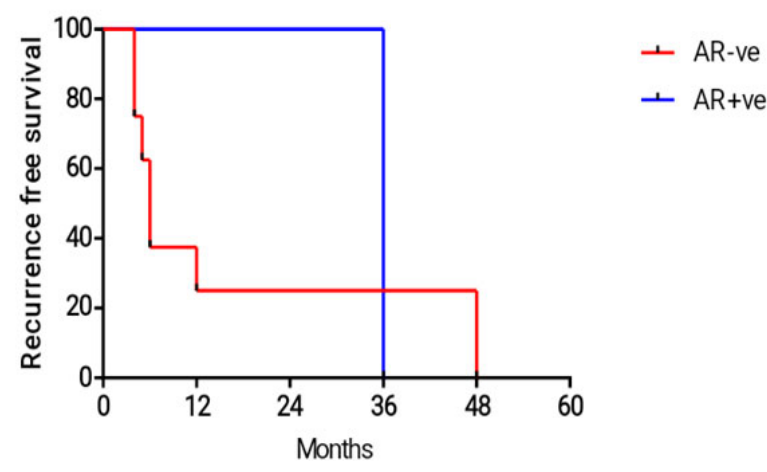

Figure 6. RFS according to AR expression

\subsection{Kaplan Meier analysis}

There was no significant association between AR expression and either recurrence free survival or progression free survival ( $p \leq .59 \& p \leq .59$ respectively). Kaplan Meier curve for recurrence free survival (RFS) for all the studied patients, over 60 months (see Figure 5) showed that the $50 \%$ of the patients had recurrence after 6 months, $60 \%$ had recurrence after 1year and all the patients had recurrence at 48 months. 
According to AR expression (see Figure 6), the RFS probability of patients showed no significant association with AR expression $(p<0.597)$.

\subsection{Progression free survival}

Kaplan Meier curve for progression free survival (PFS) for all the studied patients, over 60 months (see Figure 7) revealed that at 6 months $33.3 \%$ of the patients had progression, while at 12 months $58.3 \%$ of the patients had progression, at 18 months $70.8 \%$ of the patient had progression, at 36 months $83 \%$ of the patients had progression, and at 48 months all the patients had progression.

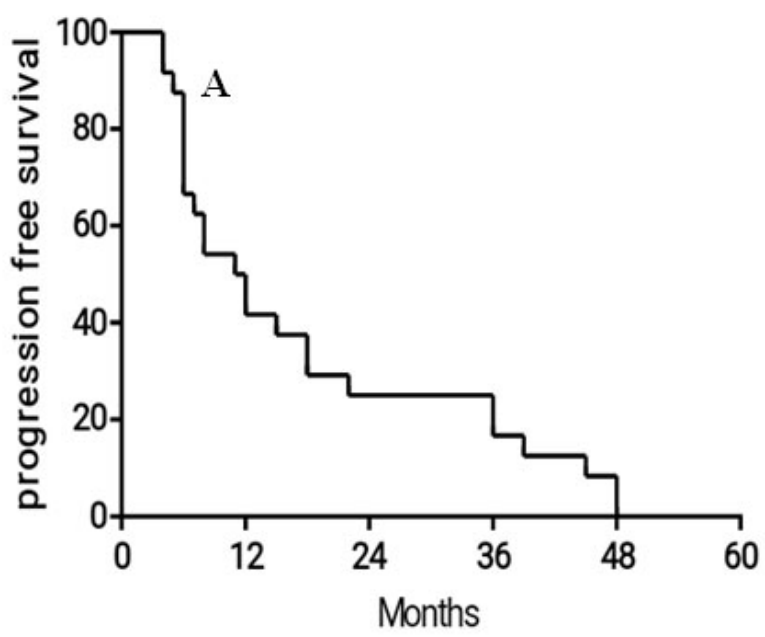

Figure 7. Kaplen Meier curve for progression free survival among all the studied patients

According to AR expression (see Figure 8), no significant association was detected between PFS and AR expression ( $p$ $<0.597)$.

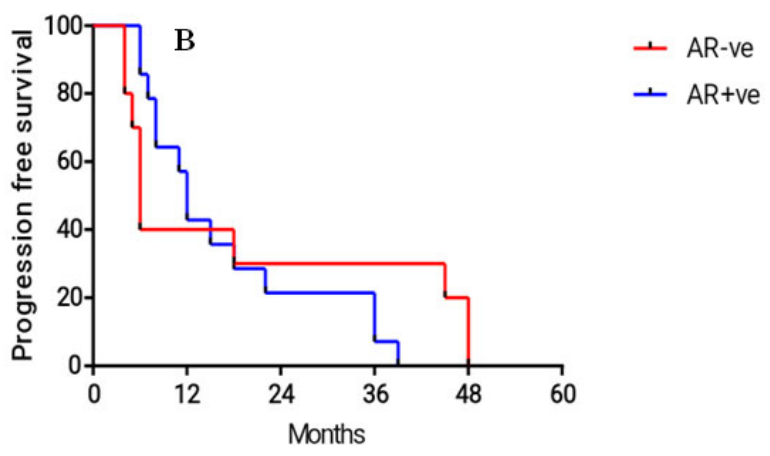

Figure 8. PFS according to AR expression

\section{Discussion}

Bladder urothelial carcinoma; is one of the most common malignancy in which $75 \%$ of newly diagnosed patients have

Published by Sciedu Press non muscle invasive disease and $25 \%$ have muscle invasive or metastatic disease. ${ }^{[4,20]}$ Considering that its management, prognosis, and mortality rates have remained essentially unchanged over the last few decades, new modality treatments are needed which necessitates new research fields. ${ }^{[21]}$

Obviously, Men are at a higher risk to have UC than women, ${ }^{[8]}$ which could highlight the significance of androgen in such neoplasm. Although UC is not considered to be an endocrine related cancer, emerging preclinical and clinical evidence have indicated the involvement of AR signals in the development and progression of UC as well as its resistance to chemotherapy $\&$ immunotherapy. ${ }^{[10,11,22]}$

In our study, we assessed the correlation between AR expression and clinicopathological variables and the disease outcome in patients with UC. Regarding AR expression, positive nuclear AR expression was reported in $75 \%$ of the studied cases which is nearly equal to the results of another study where AR expression was positive in $78 \%$ ( 7 out of 9) of the patients., ${ }^{[23]}$ positive AR expression in UC patients was ranging between $13-78 \%$ Among different studies. ${ }^{[24,25]}$

AR expression and its relations to UC clinicopathological parameters is controversial. Our results revealed that there is a positive association between AR expression and the high grade $(p \leq .001)$, advanced stage disease $(p \leq .001)$ and muscle invasion $(p \leq .001)$. These results were in agreement with one study by Mashhadi et al. (2014) ${ }^{[26]}$ which showed positive correlation between AR expression and high grade, poorly differentiated and advanced stage UC ( $p \leq$ $.001)$. On the other hand, other studies revealed negative correlation between AR expression and tumor grade, stage and muscle invasion suggesting that loss of AR expression is associated with higher pathologic stage and muscle invasive tumors. ${ }^{[27-32]}$ Moreover, other studies revealed no correlation between AR expression and grade, stage or muscle invasion. ${ }^{[25,33]}$

These data highlight the complexity of AR signaling in UC and the possibility of other signaling pathways affecting the AR signaling in carcinogenesis. All the studies revealed no difference in AR expression between males and females. ${ }^{[25-33]}$ And these results matched ours.

The role of AR expression as a prognostic tool is still debated. There is no significant association between AR expression and either recurrence free survival (RFS) or progression free survival (PFS) ( $p \leq .59 \& p \leq .59$ respectively) in the current study. This observation is similar to the results of several studies which found that AR expression has no prognostic significance. ${ }^{[25,28,30,32,33]}$ On the other hand, Mashhadi et al. $(2014)^{[26]}$ found that AR expression was significantly asso- 
ciated with higher rate of metastasis $(p \leq .009)$ and lower recurrence free survival (RFS) $(p \leq .08)$. Moreover, Nam et al. (2014) $)^{[29]}$ reported significant association between AR expression and lower recurrence rates in non muscle invasive patients $(p \leq .011)$. Despite that our study had some limitations; it is a retrospective one and the small sample size, yet it emphasizes on the significance of AR signaling in carcinogenesis of UC.

\section{Conclusion}

High grade tumor, deep muscle invasion and large tumor size of the urinary bladder are significantly associated with AR expression. Which supports a role for AR signaling in human bladder carcinogenesis and progression. Using antiandrogen in treatment of urothelial bladder carcinoma could be an effective chemo preventive or therapeutic approach.

\section{Conflicts of Interest Disclosure}

The authors declare no conflict of interest

\section{REFERENCES}

[1] Bray F, Ferlay J, Soerjomataram I, et al. Global cancer statistics 2018: GLOBOCAN estimates of incidence and mortality worldwide for 36 cancers in 185 countries. CA Cancer J Clin. 2018; 68(6): 394-424. PMid:30207593. https://doi.org/10.3322/caac. 21492

[2] Ibrahim AS, Khaled HM, Mikhail NN, et al. Cancer incidence in Egypt: results of the national population-based cancer registry program. J Cancer Epidemiol. 2014; 2014: 1-18. PMid:25328522. https://doi.org/10.1155/2014/437971

[3] Kirkali Z, Chan T, Manoharan M, et al. Bladder cancer: epidemiology, staging and grading, and diagnosis. Urology. 2005; 66 (6 Suppl 1): 4-34. PMid:16399414. https://doi.org/10.1016/j.urol ogy . 2005.07.062

[4] Jemal A, Siegel R, Ward E, et al. Cancer statistics, 2008. CA Cancer J Clin. 2008; 58(2): 71-96. PMid:18287387. https://doi .org/ 10.3322/CA. 2007.0010

[5] Knowles MA, Hurst CD. Molecular biology of bladder cancer: new insights into pathogenesis and clinical diversity. Nat Rev Cancer. 2015; 15(1): 25-41. PMid:25533674. https ://doi.org/10.103 $8 / \mathrm{nrc} 3817$

[6] Jakse G, Hall R, Bono A, et al. Intravesical BCG in patients with carcinoma in situ of the urinary bladder: long-term results of EORTC GU Group phase II protocol 30861. Eur Urol. 2001; 40(2): 144-50. PMid:11528191. https://doi.org/10.1159/000049765

[7] Powles T, Eder JP, Fine GD, et al. MPDL3280A (anti-PD-L1) treatment leads to clinical activity in metastatic bladder cancer. Nature. 2014; 515(7528): 558-62. PMid:25428503. https ://doi .org/10 $.1038 /$ nature 13904

[8] Siegel R, Naishadham D, Jemal A. Cancer statistics, 2012. CA Cancer J Clin. 2012; 62(1): 10-29. PMid:22237781. https : //doi . or $\mathrm{g} / 10.3322 /$ caac. 20138

[9] McCahy PJ, Harris CA, Neal DE. The accuracy of recording of occupational history in patients with bladder cancer. Br J Urol. 1997; 79(1): 91-3. PMid:9043504. https://doi.org/10.1046/j.14 64-410X.1997.30119.x

[10] Miyamoto H, Yang Z, Chen YT, et al. Promotion of bladder cancer development and progression by androgen receptor signals. $\mathrm{J}$ Natl Cancer Inst. 2007; 99(7): 558-68. PMid:17406000. https: //doi.org/10.1093/jnci/djk113

[11] Shiota M, Yokomizo A, Takeuchi A, et al Secondary bladder cancer after anticancer therapy for prostate cancer: reduced comorbidity after androgen-deprivation therapy. Oncotarget. 2015; 6(16): 14710-9. PMid:25900243. https://doi.org/10.18632/oncotarget. 38 17

[12] Thomas JC, Oottamasathien S, Makari JH, et al. Temporal-spatial protein expression in bladder tissue derived from embryonic stem cells. J Urol. 2008; 180(4 Suppl): 1784-9. PMid:18721943. https : //doi.org/10.1016/j.juro.2008.03.098

[13] Mangelsdorf DJ, Thummel C, Beato M, et al. The nuclear receptor superfamily: the second decade. Cell. 1995; 83(6): 835-9. https://doi.org/10.1016/0092-8674(95) 90199-X

[14] Eder IE, Culig Z, Putz T, Nessler-Menardi C, Bartsch G, Klocker H. Molecular biology of the androgen receptor: from molecular understanding to the clinic. Eur Urol. 2001; 40(3): 241-51. PMid:11684838. https://doi.org/10.1159/000049782

[15] Heemers HV, Tindall DJ. Androgen receptor (AR) coregulators: a diversity of functions converging on and regulating the AR transcriptional complex. Endocr Rev. 2007; 28(7): 778-808. PMid:17940184. https://doi.org/10.1210/er.2007-0019

[16] Chang C, Lee SO, Yeh S, et al. Androgen receptor (AR) differential roles in hormone-related tumors including prostate, bladder, kidney, lung, breast and liver. Oncogene. 2014; 33(25): 3225-34 PMid:23873027. https://doi.org/10.1038/onc.2013.274

[17] Amin MB, Edge SB, Greene FL. AJCC cancer staging manual. New York, NY: Springer; 2017.

[18] Montironi R, Lopez-Beltran A. The 2004 WHO classification of bladder tumors: a summary and commentary. Int J Surg Pathol. 2005; 13(2): 143-53. PMid:15864376. https://doi .org/10.1177/10 6689690501300203

[19] Yao JL, Ryan CK, Francis CW, et al. Tissue factor and VEGF expression in prostate carcinoma: a tissue microarray study. Cancer Invest. 2009; 27(4): 430-4. PMid:19219655. https://doi.org/10.108 $0 / 07357900802527247$

[20] Burger M, Catto JW, Dalbagni G, et al. Epidemiology and risk factors of urothelial bladder cancer. Eur Urol. 2013; 63(2): 234-41. PMid:22877502. https://doi.org/10.1016/j. eururo. 2012. 07.033

[21] Charlton ME, Adamo MP, Sun L, et al. Bladder cancer collaborative stage variables and their data quality, usage, and clinical implications: a review of SEER data, 2004-2010. Cancer. 2014; 120 Suppl 23: 3815-25. PMid:25412393. https://doi.org/10.1002/cncr.2 9047

[22] Shiota M, Takeuchi A, Yokomizo A, et al. Androgen receptor signaling regulates cell growth and vulnerability to doxorubicin in bladder cancer. J Urol. 2012; 188(1): 276-86. PMid:22608749. https://doi.org/10.1016/j.juro.2012.02.2554

[23] Zhuang YH, Blauer M, Tammela T, et al. Immunodetection of androgen receptor in human urinary bladder cancer. Histopathology. 1997; 30(6): 556-62. PMid:9205860. https://doi.org/10.104 $6 / j .1365-2559.1997 .5610801 . x$ 
[24] Ide H, Miyamoto H. Steroid Hormone Receptor Signals as Prognosticators for Urothelial Tumor. Dis Markers. 2015; 2015: 840640. PMid:26770009. https://doi .org/10.1155/2015/840640

[25] Kashiwagi E, Fujita K, Yamaguchi S, et al. Expression of steroid hormone receptors and its prognostic significance in urothelial carcinoma of the upper urinary tract. Cancer Biol Ther. 2016; 17(11): 1188-96. PMid:27635763. https://doi.org/10.1080/153840 47.2016 .1235667

[26] Mashhadi R, Pourmand G, Kosari F, et al. Role of steroid hormone receptors in formation and progression of bladder carcinoma: a casecontrol study. Urol J. 2014; 11(6): 1968-73.

[27] Boorjian S, Ugras S, Mongan NP, et al. Androgen receptor expression is inversely correlated with pathologic tumor stage in bladder cancer. Urology. 2004; 64(2): 383-8. PMid:15302512. https: //doi.org/10.1016/j.urology.2004.03.025

[28] Tuygun C, Kankaya D, Imamoglu A, et al. Sex-specific hormone receptors in urothelial carcinomas of the human urinary bladder: a comparative analysis of clinicopathological features and survival outcomes according to receptor expression. Urol Oncol. 2011; 29(1): 43-51. PMid:19372057. https://doi.org/10.1016/j.urolon c. 2009.01 .033
[29] Nam JK, Park SW, Lee SD, et al. Prognostic value of sex-hormone receptor expression in non-muscle-invasive bladder cancer. Yonsei Med J. 2014; 55(5): 1214-21. PMid:25048477. https://doi.org/ 10.3349/ymj.2014.55.5.1214

[30] Miyamoto H, Yao JL, Chaux A, et al. Expression of androgen and oestrogen receptors and its prognostic significance in urothelial neoplasm of the urinary bladder. BJU Int. 2012; 109(11): 1716-26. PMid:22221549. https://doi .org/10.1111/j.1464-410X . 20 $11.10706 . \mathrm{x}$

[31] Williams EM, Higgins JP, Sangoi AR, et al. Androgen receptor immunohistochemistry in genitourinary neoplasms. Int Urol Nephrol. 2015; 47(1): 81-5. PMid:25218615. https://doi.org/10.1007/ s11255-014-0834-7

[32] Kauffman EC, Robinson BD, Downes MJ, et al. Role of androgen receptor and associated lysine-demethylase coregulators, LSD1 and JMJD2A, in localized and advanced human bladder cancer. Mol Carcinog. 2011; 50(12): 931-44. PMid:21400613. https: //doi.org/10.1002/mc. 20758

[33] Mir C, Shariat SF, van der Kwast TH, et al. Loss of androgen receptor expression is not associated with pathological stage, grade, gender or outcome in bladder cancer: a large multi-institutional study. BJU Int. 2011; 108(1): 24-30. PMid:21070579. https: //doi.org/10.1111/j.1464-410X.2010.09834.x 